\title{
Sustainability in the Most Globalized Sectors of Creative Industries in Slovakia
}

\author{
Kristína Krúpová ${ }^{1}$ Mária Trúchliková2, and Mária Kmety Barteková2,** \\ ${ }^{1}$ University of Economics, Faculty of International Relations, Department of International Political \\ Relations, Dolnozemská cesta 1, 85235 Bratislava, Slovakia \\ ${ }^{2}$ University of Economics, Faculty of Business Management, Department of Business Economy, \\ Dolnozemská cesta 1, 85235 Bratislava, Slovakia
}

\begin{abstract}
.
Research background: To achieve long-term sustainability, it is necessary to strive for a green economy and come up with solutions to address limitations to resource footprints. This will require innovations across the board and creativity in all fields. Creativity and sustainability are closely linked. The sustainable development requires concerted efforts towards building an inclusive and resilient future for the planet. Innovation, the business of ideas, is increasingly seen as the key to future societal prosperity and business success.

Purpose of the article: The aim of the paper is to analyse the sustainable development of the most globalized sectors of the creative industries in Slovakia mainly measured by the value added. The value added according to Kalecki (1990) is the sum of wages and profits of the companies.

Methods: Sustainability, innovation and value creation (or value added) are nowadays the object of particular attention by the various stakeholders as economic institutions, public and governments.

Findings \& Value added: This is the first research paper which has used the data on value added recently calculated for the media, publishers and software enterprises, which represent the most globalized sectors of the creative industries in Slovakia. The companies with the highest value added have reached the sustainable development and the best economic performance within the media, publishers and software enterprises' sector.
\end{abstract}

Keywords: Creative industries; Globalized Economy; Sustainability; Value added

JEL Classification: $L 89 ; O 30 ; Z 10$

\section{Introduction}

The Sustainable Development Goals (SDGs) are broad reaching targets followed by European Union that aim to end poverty, protect our planet and ensure prosperity for all [1].

*Corresponding author: maria.bartekova@euba.sk 
Within the SDG 8 the European Union focused on the indicator employment rate for the measuring the sustainable development. The European Union recognises the importance of sustained economic growth and high levels of economic productivity for the creation of well-paid quality jobs and the achievement of global prosperity.

The Slovak economy is extremely globalized. In 2018, the share of exports relative to GDP was more than 94\%. The integration of the Slovak Republic into the international market has reinforced the inflow of foreign direct investment into a small number of sectors, followed by enormous technology transfers. To balance such expansions, it is necessary to enlarge internal sources of development, the economic self-sufficiency of regions and national research and development. Development based on innovations is unattainable without a creative and valuable workforce, therefore Slovakia must pay special attention to increasing its capacity to support and attract talent. Greater involvement of the private sector is also crucial as the share of research and development spending by private businesses in Slovakia is the lowest in the European Union.

Sustainable economic growth is economic development that attempts to satisfy the needs of humans but in a manner that sustains natural resources and the environment for future generations. An economy functions in the ecosystem. We cannot separate the economy from it. In fact, an economy cannot exist without it. The ecosystem provides the factors of production that fuels economic growth: land, natural resources, labour, and capital (which is created by labour and natural resources). Sustainable economic growth is managing these resources in a manner that they will not be depleted and will remain available for future generations.

Specifically, we contrast the widespread assumption of a positive direct impact of cultural heritage on economic development with an innovative idea according to which the effect of cultural heritage on development could be indirect and, in particular, that it could be mediated by creativity. In fact, creativity is expected to explain the local capability to exploit cultural heritage for economic purposes $[3,4]$.

Currently IT sector, especially software publishing companies have become one of the key technological infrastructures where existing technologies continue to rapidly develop and novel technologies are being constantly introduced, fostering the emergence of new entrepreneurial ventures. IT and their solutions are recognized as major drivers of economic growth, social changes, strengthening the competitiveness of the country, encouraging entrepreneurship and innovation, employment, and others $[5,6]$.

\section{Methods}

In this chapter, the primary research aim is described and methodology of the research is defined bellow.

\subsection{Research aim}

The aim of the paper is to analyse the sustainable economic development according to the SDG 8 of the most globalized sectors of the creative industries in Slovakia mainly measured by the value added and the volume of foreign trade. The value added according to Kalecki (1990) is the sum of wages and profits of the companies. We focused to demonstrate the dependency between the sustainable economic growth and the foreign trade and the value added. In the paper, we articulated the following research questions:

- Research question no. 1: Does any relationship exist between the sustainable economic development of the selected creative industries' sectors and the volume of foreign trade as the indicator linked to the globalization in Slovakia? 
- Research question no. 2: Does any relationship exist between the sustainable economic development of the selected creative industries' sectors and value added belonging to the group of indicators linked to the globalization in Slovakia?

\subsection{Methodology of the research}

The employment rate is a measure of economic activity and is commonly used as a indicator of the sustainable development. This indicator is reported within the SDG 17 by the EU. In our research, we set the employment rate as the independent variable. In the second regression model, the value added played the role of independent variable.

Value added reflects the value generated by producing goods and services, and is measured as the value of output minus the value of intermediate consumption. Value added also represents the income available for the contributions of labour and capital to the production process. The indicator presents value added for the most globalized sectors of the creative industries in Slovakia measured in million EURO.

The empirical part of our research consists of the analysis of the indicators measuring the globalization as the international trade of cultural goods in the EU, then the value added of the most globalized sectors and regression models describing the volume of export, value added and the employment rate representing the sustainable development of the economy. The data used in the paper were provided mainly by the Eurostat and the Statistical Office of the Slovak Republic. To find the answers for the set research questions, we used the descriptive statistics and the regression analysis as the method for examining the influence of one or more independent variables on a dependent variable.

\section{Results and Discussion}

Despite existing divergences, there is a high consensus between international scholars and researchers that creative industries are increasingly contributing to the trade and economic growth of the world, especially in developed nations $[7,8]$. The film industry and video publishing belonging to the group of the most globalized sectors in the creative industries fit the aforementioned characteristics. They have high fixed production costs, benefits from economies of scale and faces significant trade costs related to cultural distance [9].

Figure 1 shows the foreign trade of cultural goods and services as the percentage of the total foreign trade [10]. One can see that Poland, France and Italy are the European leaders in foreign trade of the cultural goods and services. Slovakia belongs to the countries which reached the lowest share of the cultural goods and services in total foreign trade. 

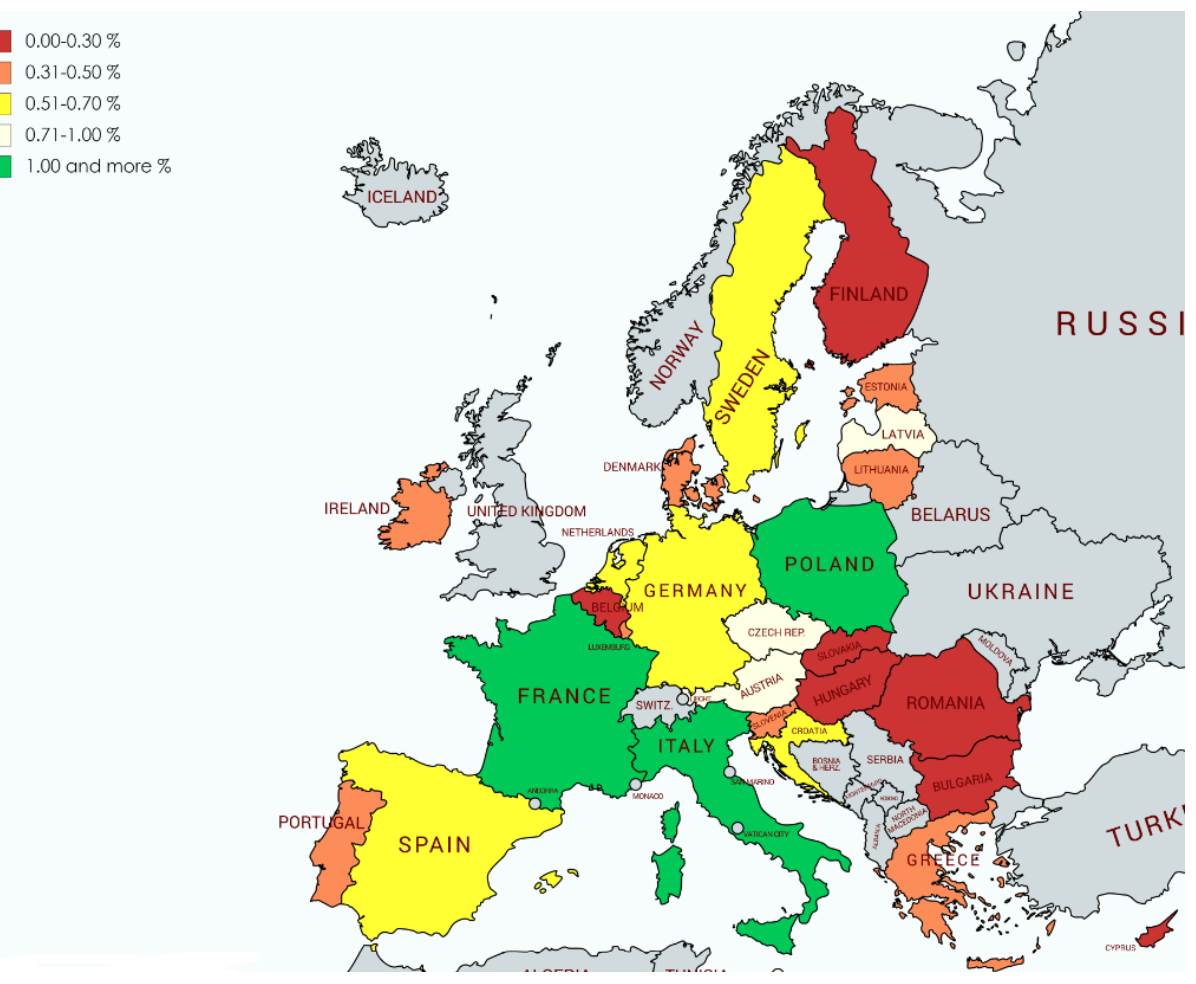

Fig. 1. Structure of Intra and extra-EU trade in cultural goods and services.

The effective demand theory, in comparison with commonly applied policies of improving the national competitive position either through wage rate reductions, or through rate of exchange depreciation, demonstrated that those policies could be ineffective in case of a single country and doomed to failure should they be applied by all countries together [1]. Under globalization the ability of any single country to run its sovereign macroeconomic policy is however severely limited. Only countries that enjoy a truly sovereign monetary policy can exercise it. Those are countries that are independent of the 'confidence' of financial world markets. In the last three years, Slovakia have reached the employment rate very close to the European average (Figure 2). According to the SDG 8 target, we confirmed that the employment rate reached in Slovakia is sustainable.

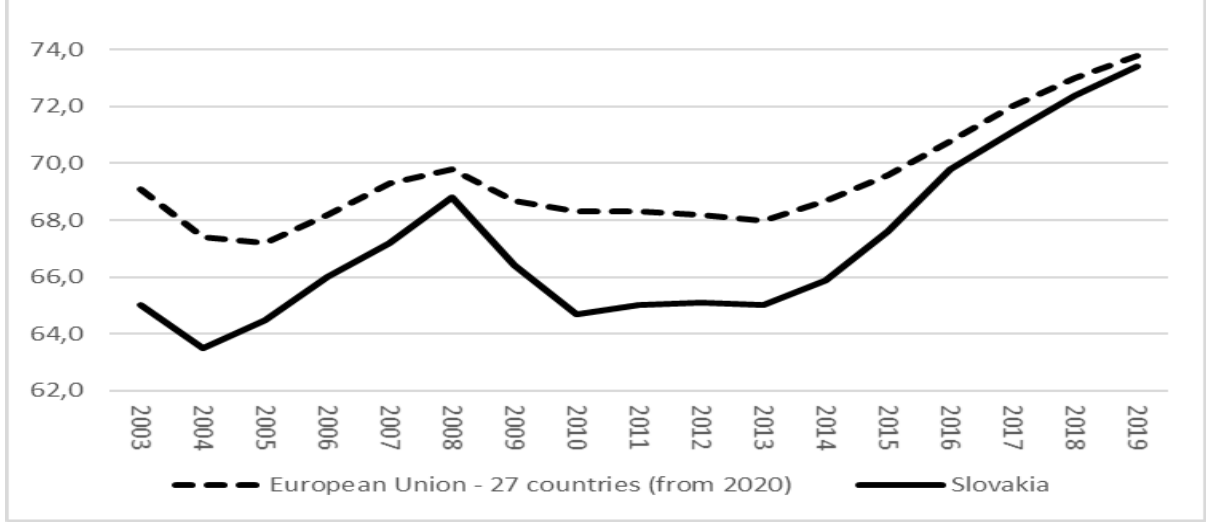

Fig. 2. Development of employment rate in Slovakia and in the EU. 
2012

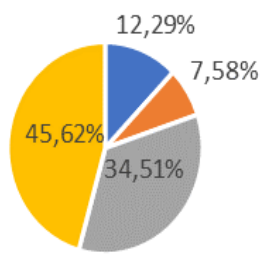

- Publishing activities

= Other professional, scientific and technical activities

= Other business support activities

2014

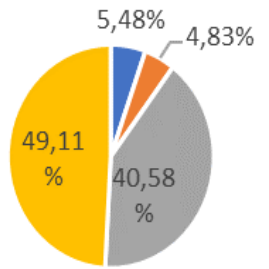

2013

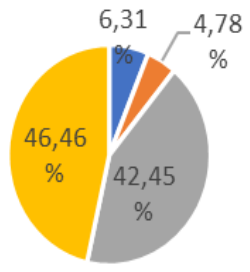

2015

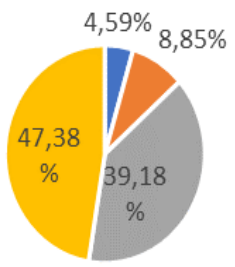

Fig. 3. Share of employees in the sectors of creative industries (2012-2015).

Figure 3 and 4 represented the share of employees in the sectors of the creative industries in Slovakia [11]. One can see that the most globalized sectors in the creative industries employed the highest number of employees. It means that these sectors reached the biggest share on employment in the creative industries.
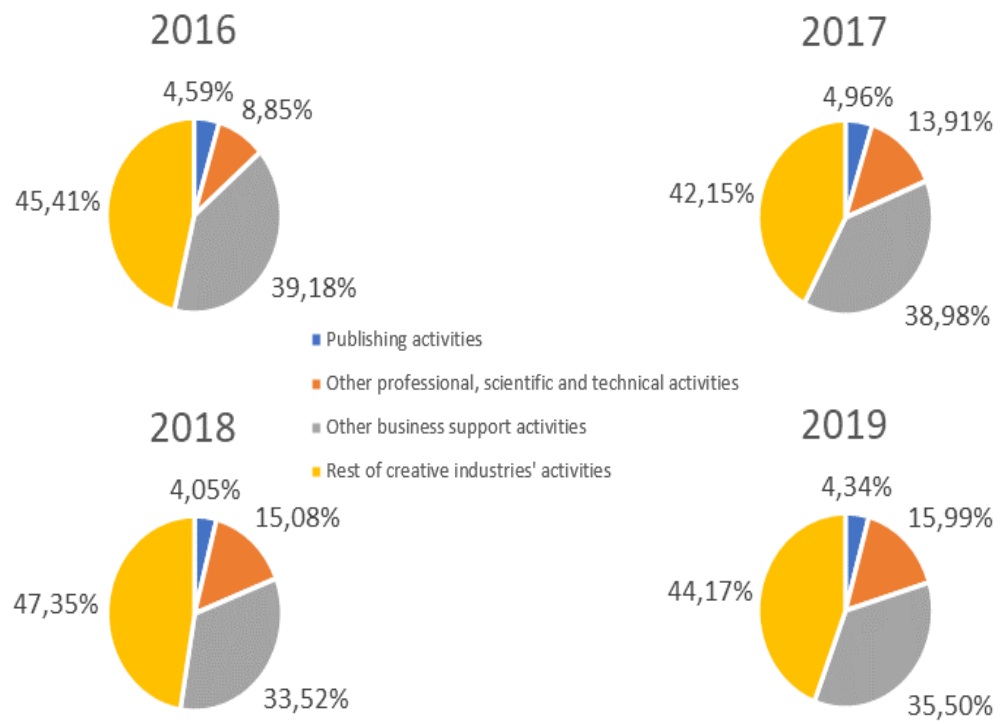

Fig. 4. Share of employees in the sectors of creative industries (2016-2019). 
The moderate positive correlation $(0,56)$ between the employment rate as the indicator measuring the sustainable development and the volume of export in the creative industries in Slovakia was confirmed (table 1). The linear dependence between these two indicators exists at the level of significance less than $75 \%$.

Table 1. Results of the regression analysis (employment rate and the volume of export).

\begin{tabular}{|c|c|c|c|c|c|}
\hline \multicolumn{4}{|c|}{ Model Summary (Export) } & & \\
\hline $\mathrm{R}$ & R Square & \begin{tabular}{|l|} 
Adjusted R \\
Square
\end{tabular} & $\begin{array}{l}\text { Std. Error of the } \\
\text { Estimate }\end{array}$ & & \\
\hline \multirow[t]{3}{*}{.56} & .32 & .15 & $680,617.97$ & & \\
\hline & \multicolumn{5}{|l|}{ ANOVA (Export) } \\
\hline & Sum of Squares & $\mathrm{df}$ & Mean Square & $\mathrm{F}$ & Sig. \\
\hline Regression & $862,279,868,689.92$ & 1 & $862,279,868,689.92$ & 1.86 & .244 \\
\hline Residual & $1,852,963,259,834.31$ & 4 & $463,240,814,958.58$ & & \\
\hline \multirow[t]{4}{*}{ Total } & $2,715,243,128,524.23$ & 5 & & & \\
\hline & \multicolumn{3}{|c|}{ Coefficients (Export) } & & \\
\hline & \multicolumn{2}{|c|}{ Unstandardized Coefficients } & $\begin{array}{l}\text { Standardized } \\
\text { Coefficients }\end{array}$ & & \\
\hline & $\mathrm{B}$ & Std. Error & Beta & $t$ & Sig. \\
\hline (Constant) & $13,396,112.74$ & $8,018,108.80$ & .00 & 1.67 & .156 \\
\hline Employment_rate & $-162,167.74$ & $118,862.19$ & -.56 & -1.36 & .244 \\
\hline
\end{tabular}

Added value is closely linked to productivity. Productivity is an indicator that, in economic terms, measures output per unit of input and thus measures how efficiently production inputs, such as labour and capital, used in the economy to produce a given level of production [12]. In the case of increasing productivity, the efficiency of the production process increases. Productivity is considered a key resource of economic growth and competitiveness. The biggest downturn of the value added was in 2012 [13]. From this period, the development of the indicators value added was slightly increasing (Figure 5).

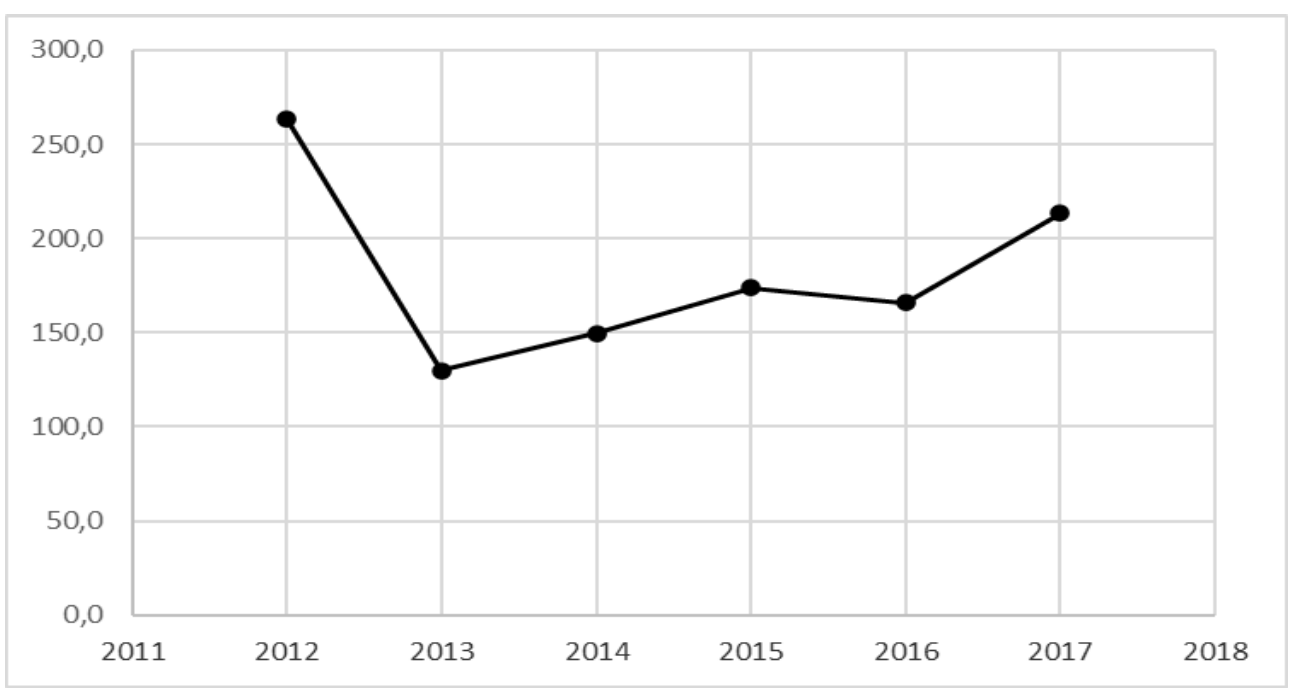

Fig. 5. Value added development of the most globalized creative sectors (in mil. EUR).

Table 2 contains the results of the regression analysis, where the employment rate in Slovakia is the dependent variable and the value added and the volume of export are independent variables. There is moderate dependence between the employment rate and the indicators value added and the volume of export of cultural goods and services $(0,64)$. But 
the level of significance is low, just around $55 \%$. F value is greater than 0,05 , so it is recommended to choose another independent variable.

Table 2. Results of the regression analysis (employment rate, the value added and the volume of export).

Model Summary (Employment rate)

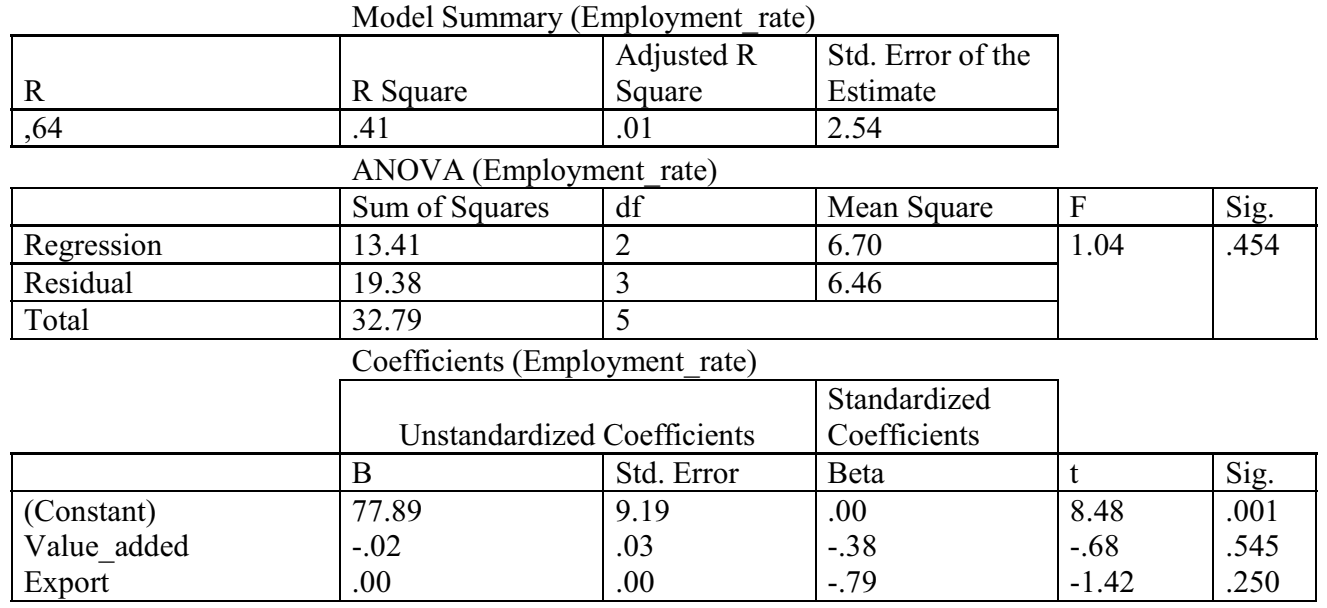

\section{Conclusions}

Slovakia is a country of high exports. Significant degree of export performance and openness of Slovakia is the result of its participation in global and especially regional value chains. Value of exports of goods and services from the country reached the amount in 2018 to $97.3 \%$ of the value of gross domestic product (GDP). At the same time, it is also an economy of significant imports, its value was at the level of $95.1 \%$ of Slovak GDP. The high value of imports as well as the high value of exports means that Slovakia is an open economy that is largely interconnected with other countries. Slovakia is part of global and especially regional value chains, as $74.3 \%$ of domestic value added is exported to the countries of the European Union (EU 27). This statement is confirmed by the fact that almost half of Slovakia's economic activity (GDP) is dependent on foreign markets. Slovakia belongs to the countries, which reached the lowest share of the cultural goods and services in total foreign trade. The most globalized sectors according to highest share on the foreign trade and the highest share of employment are the publishing activities (J58-J63), other business support activities (M72, M73) and other professional, scientific and technical activities (M74). Given the current state and the need to further increase productivity and added value in the economy, especially in creative industries, it is appropriate to support and focus on activities that are related to and complement production, for example services with higher added value (e.g. research and development, design, testing, distribution), which are the significant part of the creative industries $[14,15]$.

The moderate positive correlation between the employment rate as the indicator measuring the sustainable development, the volume of export and value added in the creative industries in Slovakia was confirmed (table 1 and 2). The linear dependence between these three indicators exists at the very low level of significance. We consider that as a limitation of this research. 
This paper is the output of the scientific grant VEGA n. 1/0708/20 "Socio-economic Determinants of Sustainable Consumption and Production in Terms of Impact on Business Performance and Competitiveness $2020^{\prime}(50 \%)$ and the internal grant project of the University of Economics in Bratislava (Faculty of Business Management) no. I-20-101-00 called "Research of Creative Industry Enterprises with regard to Their Life Cycle in the Slovak Republic" (50 \%).

\section{References}

1. Kalecki, M. (1990). Capitalism: Business cycles and full employment. Collected works Vol. I. Oxford: Clarendon Press.

2. Jarvis, P. (2020). Environmental technology for the sustainable development goals (SDGs). Environmental Technology, 41(17), 2155-2156.

3. Cerisola, S. (2019). A new perspective on the cultural heritage-development nexus: The role of creativity. Journal of Cultural Economics, 43(1), 21-56.

4. Cerisola, S. (2018). Creativity and local economic development: The role of synergy among different talents. Papers in Regional Science, 97(2), 199-209.

5. Vekic, A., Djakovic, V., Borocki, J., Sroka, W., Popp, J., Olah, J. (2020). The Importance of academic new ventures for sustainable regional development. Amfiteatru Economic, 22(54), 533-550.

6. Foxall, K., Nailor, A. (2016). Sustainability in open access publishing: The ecancer case study. Learned Publishing, 29(2), 113-117.

7. Dong, C.V., Truong, H.Q. (2020). The determinants of creative goods exports: evidence from Vietnam. Journal of Cultural Economics, 44(2), 281-308.

8. Waldfogel, J. (2020). Dining out as cultural trade. Journal of Cultural Economics, 44(2), 309-338.

9. Alaveras, G., Gomez-Herrera, E., Martens, B. (2018). Cross-border circulation of films and cultural diversity in the EU. Journal of Cultural Economics, 42(4), 645-676.

10. Eurostat, (2020, 23 July). Intra and extra-EU trade in cultural goods and services. Retrieved from https://appsso.eurostat.ec.europa.eu/nui/show.do?dataset=cult_trd_prd\&lang=en.

11. Eurostat, (2020, 23 July). Cultural employment by NACE Rev. 2 activity. Retrieved from https://appsso.eurostat.ec.europa.eu/nui/show.do?dataset=cult_emp_n2\&lang=en

12. Wusrt, B. (2019). Globalization and Sustainability of Regions: The Role of Cultural and Creative Industries in Cultural Policies and their Implications for Regional Development - A Case Study of the Czech Republic. In T. Kliestik (Eds.), $19^{\text {th }}$ International Scientific Conference Globalization and Its Socio- Economic Consequences - Sustainability in the Global-Knowledge Economy (pp. 1-8). Rajecke Teplice: University Zilina.

13. Eurostat, (2020, 01 August). Value added and turnover of enterprises in the cultural sectors by NACE Rev. 2 activity. Retrieved from https://appsso.eurostat.ec.europa.eu/nui/submitViewTableAction.do.

14. Banks, M. (2020). Persistent creativity: making the case, for art, culture and the creative industries. International Journal of Cultural Policy, 26(5), 709-710.

15. Pavlovsky, B. (2018). Austrian foreign cultural policy: Europeanization through the prism of national interests. International Journal of Cultural Policy, 25(7), 933-945. 